\title{
The Weakness Examination of Wireless Network Security at the Hospital using QoS
}

\author{
Kharisma Riyanti, Sutejo, M. Ilayaraja, K. Shankar, Phong Thanh Nguyen, Wahidah Hashim, \\ Andino Maseleno
}

\begin{abstract}
Computer networks today are a much needed service. Computer networks enable the shared use of data, software and tools. So that the working group can be communicate more effectively and efficiently. This study aims to determine the existing QoS in Surya Asih Hospital and analyze the deficiencies. (Bahasa: Hospital is Rumah Sakit (RS)) In this research started from collecting data that exist in location either that support hardware or connection internet RS Surya Asih have used Wireless Local Area Network (WLAN) network service. WLAN is a network where can be exchanged data and resources between computers in one building. To know the performance of WLAN network (Wireless Local Area Network In RS Surya Asih, it should be done a measurement analysis of network performance parameters QoS (Quality of Services) is the ability to guarantee the delivery of important data flow Analysis of the performance of WLAN (Wireless Local Area Network) Surya Asih stressed the process of monitoring and measuring network parameters on the network infrastructure such as access speed and transmission capacity, from the point of delivery to the point of receiver that became the demands, the parameters used Bandwidth, Throughput, Delay and Packet Loss. Superior LAN on RS Surya Asih has reliability sufficient maintenance and good network availability Analysis of network performance is seen through Wireshark, Uptime and Downtime results are not bad, The availability of complete devices and fulfilled according to reliability and maintenance is not difficult. QoS parameter test results that bandwidth management shows the use of more bandwidth and evenly distributed to every user of RS Surya Asih Pringsewu network.
\end{abstract}

Keywords: Wifi, Wireless Network Security, Quality of Services.

\section{INTRODUCTION}

\subsection{Background}

The development of the telecommunications world today is very rapid along with the increasing need for services which are fast and efficient [1].

Revised Manuscript Received on July 22, 2019

* Correspondence Author

Kharisma Riyanti, Department of Information Systems, STMIK Pringsewu, Lampung, Indonesia.

Sutejo, Department of Information Systems, STMIK Pringsewu, Lampung, Indonesia.

M. Ilayaraja, Department of Computer Science and Information Technology, Kalasalingam Academy of Research and Education, Krishnankoil, India. E-mail: ilayaraja.m@klu.ac.in

K. Shankar, Department of Computer Applications, Alagappa University, Karaikudi, India.

Phong Thanh Nguyen*, Department of Project Management, Ho Chi Minh City Open University, Vietnam. E-mail: phong.nt@ ou.edu.vn

Wahidah Hashim, Institute of Informatics and Computing Energy, Universiti Tenaga Nasional, Malaysia.

Andino Maseleno, Institute of Informatics and Computing Energy, Universiti Tenaga Nasional, Malaysia.
Same with the communication data, start from connections between two computers to computer networks [2]. The computer networks are an indispensable service [3]. The computer networks have more benefits compared to a stand-alone computer [4]. The computer networks enable the sharing of data, software and equipment [5]. So that the working group can be communicate more effectively and efficiently [6].

Surya Asih Hospital is one of uses telecommunications, especially in the internet network section. The internet network is needed to communicate between the rooms and the buildings in hospital. QoS (Quality of Service) is a technology which applied in computer network to give optimal and fair services for computer network users. QoS enable administrator network to can to be able to handle various effects due to congestion on packet traffic on the network.

The result of QoS (Quality of Service) analysis can be made recommendations to implement the physical internet network which hopes that the future can be support the addition of services which can be support office activities. In this research measures the internet network service from parameters of delay / latency, jitter, packet loss and throughput.

Based on the research background above, so the problem research appears to be formulated as follows: The Weakness Analysis of Wireless Network Safety by RS. Surya Asih using QoS.

\subsection{Research Question}

a. How to do QoS analysis?

b. How to analyze the weaknesses of WiFi networks?

1.3 Objective and Benefit of the Research

The objectives of holding this research are:

a. Determining QoS are there in RS Surya Asih.

b. Analyzing the weakness of WiFi network.

\section{LITERATURE REVIEW}

\subsection{The Theory Which Concerned With The Research}

\subsubsection{The Computer Network}

The computer network is a combination of computer technology and telecommunications technology [7]. This combined technology breed data processing which be able distributed, including the use of databases, application software and hardware equipment together, so that the use of computers that were 
previously only independent, now it has been replaced by a group of computers which are separate however interrelated in carrying out their duties [8].

\subsubsection{The Bandwidth}

Bandwitdh is the width of the path used for the data transmission or network speed. The different applications require different bandwidths.

\subsubsection{Wireless}

Wireless (Nirkabel Network) is a communication network between computers using radio frequency. It often called a WiFi or WLAN network. Wireless Local Area Network is a local computer network which uses the radio waves as a medium for data transmission.

\subsubsection{The Quality of Service}

The ability of a network to prepare the best service for the traffic services which through it. QoS is a system architecture end to end and it is not a feature which is owned by the network.

\subsubsection{The WiFi Network Mode}

The Wifi optimization techniques cannot be separated from the connection mode a WiFi network. The Wifi techniques basically is a way where $\mathrm{Wi}-\mathrm{Fi}$ devices can be connected efficiently and regularly so that the performance of each client can work effectively.

\subsubsection{The Network Security}

The network security is a way or system which used to give protection on the network so that it avoids external threats which be able damage the network [9]. The purpose of making network security is for anticipating network risks in the form of physical threats or logic either directly or indirectly which can disturb activity ongoing in the network [10].

One thing that needs to be remembered there is not network which anti-tapping or there is network which really security because network properties is do communication, and each communication can fall into other people's hands and in the wrong using [11]. Therefore network security is very needed.

Which must be doing is recognize a number of network security threats. Attack to information system security (security attack) lately there is often a computer crime / cyber crime in cyberspace is often done by groups of people who want to penetrate a security the system.

There are some possible types of attacks carried out by the attacker are:

- Interception is the part which is not have the authority has succeeded getting the information access rights [12].

- Interruption is attacker which has been able to mastering the system, but it is not whole. Because the native administrator still can be login [13].

- Fabrication is attacker has inserted fake object into the target system [14].
- Modification is attacker has damage the system and has changed the whole [15].

\subsubsection{Analysis}

Analysis is activity which contain a number of activities like parsing, differentiate, sort out something to be classified and grouped based on suitable criteria then it is looked for the relation and interpreted its meaning [16]. In other meaning, analysis is attitude or attention to things (noun, fact, phenomena) until you can decompose into parts, and know the connection between these sections in its entirety [17].

Analysis can be also interpreted as solving ability or decipher a material or information become smaller components so it is easier to understand [18].

\subsubsection{The Internet Working}

The meaning of the internet working is a combination network of two or more computer devices in around the world and it can be said that a set of computer devices is the largest in the world, and advance in this world [19]. However a set of computer devices is only half of some definition about an internet working, because when we discuss the internet network so it aimed at [20].

\subsection{The Theory about the System Used.}

\subsubsection{Quality of Service ( $Q o S)$}

QoS is the ability of a network to prepare the good service by preparing bandwith, resolve jitter and delay. QoS parameter is latency, jitter, packet loss, throughput, MOS, echo cancellation and PDD. QoS is very determined by network quality which used. There are several factors can decrease value QoS, like : distortion, and noise.

\section{QoS parameter is:}

\section{Packet loss}

Is a parameter draws the condition which show the total number of packages lost, can occur because collision and congestion on the network and this matter on all applications because transmission will reduce overall network efficiency although amount of the bandwidth available enough for the applications.

Table 1 below shows Packet Loss Category

\begin{tabular}{|l|l|l|}
\hline $\begin{array}{c}\text { Degradation } \\
\text { Category }\end{array}$ & $\begin{array}{l}\text { Packet } \\
\text { Loss }\end{array}$ & Index \\
\hline Very good & $0 \%$ & 4 \\
\hline Good & $3 \%$ & 3 \\
\hline Good enough & $15 \%$ & 2 \\
\hline Bad & 25 & 1 \\
\hline
\end{tabular}




\section{Delay}

Is time which needed the data to traveled distances from the origin to goal. Delay can be influenced by distance, physical media, congestion or also a long process time.

Table 2 below shows delay category

\begin{tabular}{|l|l|l|}
\hline $\begin{array}{r}\text { Latency } \\
\text { Category }\end{array}$ & $\begin{array}{l}\text { Big } \\
\text { Delay }\end{array}$ & Index \\
\hline Very good & $<150 \mathrm{~ms}$ & 4 \\
\hline Good & $\begin{array}{l}150 \quad \text { up } \\
300 \mathrm{~ms} \text { to }\end{array}$ & 3 \\
\hline Good enough & $\begin{array}{l}300 \quad \text { up } \\
450 \mathrm{~ms} \text { to }\end{array}$ & 2 \\
\hline Bad & $>450 \mathrm{~ms}$ & 1 \\
\hline
\end{tabular}

3. Jitter

Jitter commonly is called variation delay, related closely to latency, show many variations delay on the data transmission of the network.

Table 3 below shows Jitter category

\begin{tabular}{|l|l|l|}
\hline $\begin{array}{l}\text { Degradation } \\
\text { Category }\end{array}$ & Peak Jitter & Index \\
\hline $\begin{array}{l}\text { Very } \\
\text { Good }\end{array}$ & $0 \mathrm{~ms}$ & 4 \\
\hline Good & $0 \mathrm{~s} / \mathrm{d} 75 \mathrm{~ms}$ & 3 \\
\hline Good enough & $75 \mathrm{~s} / \mathrm{d} 125 \mathrm{~ms}$ & 2 \\
\hline Bad & $125 \mathrm{~s} / \mathrm{d} 225 \mathrm{~ms}$ & 1 \\
\hline
\end{tabular}

\section{Throughput}

Is the rate transfer effective data, which is measured in bps. Throughput is the total number of packet arrivals which success observed at the goal during the time interval is divided by the duration of the time interval.

Table 4 Throughput Category

\begin{tabular}{|l|c|l|}
\hline $\begin{array}{l}\text { Throughput } \\
\text { Category }\end{array}$ & Throughput & Index \\
\hline $\begin{array}{l}\text { Very } \\
\text { good }\end{array}$ & $100 \%$ & 4 \\
\hline Good & $75 \%$ & 3 \\
\hline Good enough & $50 \%$ & 2 \\
\hline Bad & $<25 \%$ & 1 \\
\hline
\end{tabular}

\section{METHODOLOGY}

\subsection{Method of Data Collection}

a. Observation Method

Observation was collecting data method by using the internet directly to the object examined [21].

\section{b. Interview Method}

Interview Method was collecting the information data method used the internet by doing testing directly with the user RS Surya Asih [22].

\section{c. Literature review}

was stages carried out by studying the reference books or the sources relating to the research title [23].

\section{RESULT AND DISCUSSION}

\subsection{Testing}

Quality of Service (QoS) was an ability network to prepare the good service by preparing bandwith, resolved jitter and delay. QoS parameter was latency, jitter, packet loss, throughput, MOS, echo cancellation and PDD. QoS was very determined by network quality used. There was some factors could decrease the QoS value, like : Damping, Distortion, and Noise. Delay was the total delay time a pocket caused by transmission process from one point to another which be the destination, while Packet Loss (error) was a parameter which draw a condition show the total number of packages lost. One of packet loss causes was queue that exceeds the buffer capacity at each node. As for the results of the delay testing was conducted at Surya Asih Pringsewu Hospital, the results of the delay testing.

\subsubsection{Packet Loss Measurement}

Packet loss measurement was in the nursing building, Midwifery Building and TU Building and based on Packet Loss value in according with the TIPHON version as standard, to category Packet Loss "very good" if $0 \%$, "good" if $3 \%$, "good enough" if $15 \%$, and "bad" if $25 \%$ so it was obtained average of Packet Loss Index to each building and room in the morning between 07.30 a.m -12.00 p.m West Indonesia Time. In the afternoon between 12.00 p.m -15.00 p.m West Indonesia Time and in the evening between 18.00 p.m -24.00 pm West Indonesia Time was "very good" with the index value " 4 ".

\begin{tabular}{|c|c|c|c|}
\hline \multirow[t]{2}{*}{ Location } & \multirow{2}{*}{$\begin{array}{l}\text { Averag } \\
\text { e } \\
\text { Packet } \\
\text { Loss }\end{array}$} & \multicolumn{2}{|c|}{$\begin{array}{l}\text { Aver } \\
\text { age }\end{array}$} \\
\hline & & Index & Category \\
\hline $\begin{array}{l}\text { Nursing } \\
\text { Building }\end{array}$ & $0 \%$ & 4 & Very good \\
\hline $\begin{array}{c}\text { Midwifery } \\
\text { Building }\end{array}$ & $0 \%$ & 4 & Very good \\
\hline
\end{tabular}




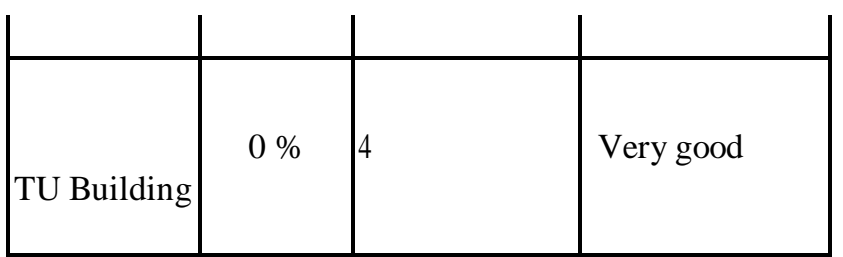

\subsubsection{Jitter Measurement}

Jitter measurement was at the nursing building, midwifery building and TU building and based on Jitter value suitable with the TIPHON version as standard, for Jitter category "very good" if $0 \mathrm{~ms}$, "good" if $0 \mathrm{~ms} \mathrm{~s} / \mathrm{d} 75 \mathrm{~ms}$, "good enough" if $75 \mathrm{~ms} \mathrm{~s} / \mathrm{d} 125 \mathrm{~ms}$, and "bad" if $125 \mathrm{~ms} \mathrm{~s} / \mathrm{d} 225 \mathrm{~ms}$ so it was gotten the Jitter Index Average to each building to each room in the morning between 07.30 a.m - 12.00 p.m West Indonesia Time, in the afternoon between 12.00 p.m- 15.00 p.m West Indonesia Time, and 18.00 a.m Wib - 24.00 p.m West Indonesia Time is "god" with the index value " 3 ".

\begin{tabular}{|l|l|l|l|}
\hline Location & Average & \multicolumn{2}{|c|}{ Average } \\
\hline & Jitter & Index & Category \\
$\begin{array}{l}\text { nursing } \\
\text { building }\end{array}$ & $5 \mathrm{~ms}$ & 3 & Good \\
$\begin{array}{l}\text { Midwifery } \\
\text { Building }\end{array}$ & $7 \mathrm{~ms}$ & 3 & Good \\
$\begin{array}{l}\text { TU } \\
\text { Building }\end{array}$ & $7 \mathrm{~ms}$ & 3 & Good \\
\hline
\end{tabular}

\subsubsection{Delay Measurement}

Delay measurement was at the nursing building, Midwifery Building and based on Delay value suitable with TIPHON version as standardization, to Delay category very good if < $150 \mathrm{~ms}$, good if $150 \mathrm{~ms} \mathrm{~s} / \mathrm{d} 300 \mathrm{~ms}$, good enough if $300 \mathrm{~ms}$ $\mathrm{s} / \mathrm{d} 450 \mathrm{~ms}$, and bad if $>450 \mathrm{~ms}$ so it was obtained Average Delay Index each building for each room in the morning between 07.30 a.m- 12.00 p.m West Indonesia Time, in the afternoon between 12.00 p.m - 15.00 p.m West Indonesia Time, and in the evening between 18.00 p.m -24.00 p.m is "very good" with Index value "4".

\begin{tabular}{|c|c|c|c|}
\hline \multirow[t]{2}{*}{$\begin{array}{l}\text { Locatio } \\
n\end{array}$} & \multirow{2}{*}{$\begin{array}{l}\text { Average } \\
\text { Delay }\end{array}$} & \multicolumn{2}{|c|}{ Average } \\
\hline & & Index & Category \\
\hline $\begin{array}{l}\text { nursing } \\
\text { building }\end{array}$ & $30 \mathrm{~ms}$ & 4 & Very good \\
\hline $\begin{array}{l}\text { midwifery } \\
\text { building }\end{array}$ & $42 \mathrm{~ms}$ & 4 & Very good \\
\hline
\end{tabular}

Throughput measurement was at the nursing building, midwifery building and TU building at the first floor, the second floor and the third floor and based on Throughput value suitable with TIPHON version as standardization, to Throughput category very good if Throughput percentage $100 \%$, good if Throughput percentage $75 \%$, but if Throughput percentage $50 \%$, and bad if Throughput percentage $>25 \%$ so obtained Average of Throughput Index to each building to each room in the morning between 07.30 a.m - 12.00 a.m West Indonesia Time, in the afternoon between 12.00 p.m - 15.00 p.m West Indonesia Time. In the afternoon between 15.00 p.m -18.00 p.m West Indonesia Time, and in the evening 18.00 p.m - 24.00 p.m West Indonesia Time.

\begin{tabular}{|c|c|c|c|}
\hline Location & Time & $\begin{array}{l}\text { Average } \\
\text { Through } \\
\text { put } \\
(\%)\end{array}$ & $\begin{array}{l}\text { Total } \\
\text { Category } \\
(\%)\end{array}$ \\
\hline $\begin{array}{l}\text { Nursing } \\
\text { Building }\end{array}$ & $\begin{array}{l}\text { Morning }(07.30-12.00) \\
\text { Wit } \\
\text { Afternoon } \\
(12.00-15.00) \mathrm{Wit} \\
\text { Afternoon } \\
(15.00-18.00) \mathrm{Wit} \\
\text { Evening }(18.00-24.00) \\
\text { Wit }\end{array}$ & $78 \%$ & $\begin{array}{l}48 \\
20 \\
1\end{array}$ \\
\hline $\begin{array}{c}\text { Midwife } \\
\text { ry } \\
\text { Building }\end{array}$ & $\begin{array}{l}\text { Morning }(07.30-12.00) \\
\text { Wib } \\
\text { Afternoon } \\
(12.00-15.00) \mathrm{Wib} \\
\text { Afternoon } \\
(15.00-18.00) \mathrm{Wib} \\
\text { Evening } \\
(18.00-24.00) \mathrm{Wib}\end{array}$ & $75 \%$ & $\begin{array}{l}43 \\
36\end{array}$ \\
\hline $\begin{array}{c}\text { TU } \\
\text { Buildin } \\
\mathrm{g}\end{array}$ & $\begin{array}{l}\text { Morning }(07.30-12.00) \\
\text { Wib } \\
\text { Afternoon } \\
(12.00-15.00) \mathrm{Wib} \\
\text { Afternoon } \\
(15.00-18.00) \mathrm{Wib} \\
\text { Evening }(18.00-24.00) \\
\text { Wib }\end{array}$ & $74 \%$ & $\begin{array}{c}23 \\
0\end{array}$ \\
\hline
\end{tabular}


The total of Throughput percentage was nursing building on category "very good" was $31 \%$, "Good" was $48 \%$, "Good Enough" was $20 \%$ and "Bad" was $1 \%$ by Throughput average was $78 \%$.

The total of Throughput percentage was Midwifery building on category "Very good" was $43 \%$, "Good" was 36 $\%$, "Good enough" was $18 \%$ and "Bad" was $3 \%$ by Throughput average was $75 \%$.

The total of Throughput percentage was Midwifery building on category "Very good" is $36 \%$, "Good" is $41 \%$, "Good enough" was $23 \%$ and "Bad" was $0 \%$ by Throughput average was $74 \%$.

\subsection{Analysis}

\subsubsection{Weakness}

From the discussion above, the researcher determined the weaknesses of the wifi network are:

1. The Access Point Tool was outside the Midwifery Building potentially struck by lightning

2. With a good signal which was covered around RS Surya Asih, potentially wifi was broken by irresponsible people.

And the following tips to resolve existing weaknesses:

1. Install the frequency access point $5 \mathrm{ghz}$ to reduce the wifi theft which was often happen.

2. Limit active usage through the router.

3. Install the lightning rod around the radio access point to avoid getting struck by lightning

\section{CONCLUSION/ RECOMMENDATIONS}

\subsection{Conclusion}

Based on the discussion of this research was obtained, some conclusion was:

a. The QoS parameter testing result was bandwidth management showed bandwith usage be better and equally for each network usage RS Surya Asih Pringsewu

b. The management of point access location was very good so that ping between the building was not too far difference included in the best category

c. Hardware device would be better when it was upgrade to wireless with the frequency $5 \mathrm{ghz}$ to existing network security.

\subsection{Suggestion}

Using QoS parameter was for the research result more accurate, was latency, jitter, packet loss, throughput, MOS, echo cancellation, error, Out Of Delivery and PDD. Observation time had to suitable with the cross internet network condition in Surya Asih Hospital. Surya Asih Hospital party had to make internet management so that the internet theft could be minimized.

\section{REFERENCES}

1. Chienwattanasook, K., Wattanapongphasuk, W., Prianto, A., \& Jermsittiparsert, K. 2019. "Corporate Entrepreneurship and Business Performance of Logistic Companies in Indonesia." Industrial Engineering \& Management Systems 18 (3): 538-547.

2. Dawabsheh, M., Hussein, A., \& Jermsittiparsert, K. 2019. "The Triangular Relationship between TQM, Organizational Excellence and Organizational Performance: A Case of Arab American University Palestine.” Management Science Letters 9 (6): 921-932.

3. Jermsittiparsert, K., Siam, M., Issa, M., Ahmed, U., \& Pahi, M. 2019 "Do Consumers Expect Companies to Be Socially Responsible? The Impact of Corporate Social Responsibility on Buying Behavior." Uncertain Supply Chain Management 7 (4): 741-752.

4. Syazali, M., Putra, F., Rinaldi, A., Utami, L., Widayanti, Umam, R., \& Jermsittiparsert, K. 2019. "Partial Correlation Analysis Using Multiple Linear Regression: Impact on Business Environment of Digital Marketing Interest in the Era of Industrial Revolution 4.0." Management Science Letters 9 (11): 1875-1886.

5. Sae-Lim, P. \& Jermsittiparsert, K. 2019. "Is the Fourth Industrial Revolution a Panacea? Risks toward the Fourth Industrial Revolution: Evidence in the Thai Economy." International Journal of Innovation, Creativity and Change 5 (2): 732-752.

6. Chatchawanchanchanakij, P., Arpornpisal, C., \& Jermsittiparsert, K. 2019. "The Role of Corporate Governance in Creating a Capable Supply Chain: A Case of Indonesian Tin Industry." International Journal of Supply Chain Management 8 (3): 854-864.

7. Hartinah, S., Suharso, P., Umam, R., Syazali, M., Lestari, B., Roslina, R., \& Jermsittiparsert, K. 2020. "Teacher's Performance Management: The Role of Principal's Leadership, Work Environment and Motivation in Tegal City, Indonesia." Management Science Letters 10 (1): 235-246.

8. Haseeb, M., Hussain, H., Slusarczyk, B., \& Jermsittiparsert, K. 2019. "Industry 4.0: A Solution towards Technology Challenges of Sustainable Business Performance." Social Sciences 8 (5): 184

9. Haseeb, M., Hussain, H., Kot, S., Androniceanu, A., \& Jermsittiparsert, K. 2019. "Role of Social and Technological Challenges in Achieving a Sustainable Competitive Advantage and Sustainable Business Performance." Sustainability 11 (14): 3811.

10. Haseeb, M., Kot, S., Hussain, H., \& Jermsittiparsert, K. 2019. "Impact of Economic Growth, Environmental Pollution, and Energy Consumption on Health Expenditure and R and D Expenditure of ASEAN Countries." Energies 12 (19): 3598.

11. Huda, S., Tsani, I., Syazali, M., Umam, R., \& Jermsittiparsert, K. 2020. "The Management of Educational System Using Three Law Auguste Comte: A Case of Islamic Schools.” Management Science Letters 10 (3) (In press), DOI: 10.5267/j.msl.2019.9.018.

12. Usak, M., Kubiatko, M., Shabbir, M., Dudnik, O., Jermsittiparsert, K., \& Rajabion, L. 2019. "Health Care Service Delivery Based on the Internet of Things: A Systematic and Comprehensive Study." International Journal of Communication Systems 32 (14): e4179.

13. Jermsittiparsert, K., Ambarita, D., Mihardjo, L., \& Ghani, E. 2019 "Risk-Return through Financial Ratios as Determinants of Stock Price: A Study from ASEAN Region." Journal of Security and Sustainability Issues 9 (1): 199-210.

14. Thabhiranrak, T. \& Jermsittiparsert, K. 2019. “Towards Sustainable Functioning of Organization: Women Empowernment and Corporate Management Culture.” Journal of Security and Sustainability Issues 9 (1): 321-332.

15. Maseleno, A., Hardaker, G., Sabani, N., \& Suhaili, N. (2016). Data on multicultural education and diagnostic information profiling: Culture, learning styles and creativity. Data in brief, 9, 1048.

16. Maseleno, A., Huda, M., Jasmi, K. A., Basiron, B., Mustari, I., Don, A G., \& bin Ahmad, R. (2019). Hau-Kashyap approach for student's level of expertise. Egyptian Informatics Journal, 20(1), 27-32.

17. Maseleno, A., Huda, M., Siregar, M., Ahmad, R., Hehsan, A., Haron, Z., ... \& Jasmi, K. A. (2017). Combining the previous measure of evidence to educational entrance examination. Journal of Artificial Intelligence, 10(3), 85-90.

18. Chienwattanasook, K. \& Jermsittiparsert, K. 2019. "Impact of Entrepreneur Education on Entrepreneurial Self-Employment: A Case Study from Thailand." Polish Journal of Management Studies 19 (1): 106-116.

19. Jermsittiparsert, K., Sutduean, J., Sriyakul, T., \& Khumboon, R. 2019 "The Role of Customer Responsiveness in Improving the External Performance of an Agile Supply Chain." Polish Journal of Management Studies 19 (2): 206-217. 
20. Jermsittiparsert, K., Sutduean, J., \& Sriyakul, T. 2019. "Effect of Service Innovation and Market Intelligence on Supply Chain Performance in Indonesian Fishing Industry." Industrial Engineering \& Management Systems 18 (3): 408-417.

21. Jermsittiparsert, K., Namdej, P., \& Somjai, S. 2019. "Green Supply Chain Practices and Sustainable Performance: Moderating Role of Total Quality Management Practices in Electronic Industry of Thailand." International Journal of Supply Chain Management 8 (3): 33-46.

22. Somjai, S. \& Jermsittiparsert, K. 2019. "The Trade-off between Cost and Environmental Performance in the Presence of Sustainable Supply Chain." International Journal of Supply Chain Management 8 (4): 237-247.

23. Jermsittiparsert, K. \& Sawasdee, A. 2012. "Formal Education for Non-Thai or Undocumented Person in Thailand amidst the Challenge of Nationalism and Transnationalism: A Case Study of Wat Sirimongkhol School, Samut Sakhon Province.” Kasetsart Journal - Social Sciences 33 (2): 203-213. 